\title{
TRADISI ZIARAH KUBUR MASYARAKAT SASAK (STUDI KASUS MAKAM LOANG BALOQ)
}

\author{
Rosada', Wawansyah ${ }^{2}$ \\ ${ }^{1}$ Pendidikan Sejarah, Universitas Muhammadiyah Mataram, Ros_ada84@yahoo.co.id \\ ${ }^{2}$ Pendidikan Sejarah, Universitas Muhammadiyah Mataram
}

\section{INFO ARTIKEL}

RiwayatArtikel:

Diterima:07-04-2017

Disetujui:08-05-2017

\section{Kata Kunci:}

1. Ziarah kubur

2. masyarakat

\section{A. LATAR BELAKANG}

Kebudayaan yang terdapat di masyarakat sangat beragam, diantaranya berupa kepercayaan.Adat istiadat dan nilai-nilai sosial budaya yang mengikat dalam masyarakat.Juga terdapat nilai-nilai kepercayaan, nilai religi yang merupakan tradisi atau warisan leluhur.Budaya spiritual, adat istiadat dan nilai kepercayaan yang sudah menjadi tradisi leluhur dan nenek moyang yang merupakan bentuk prilaku yang dilakukan secara terus menerus dan akhirnya dilakukan juga oleh masyarakat atau generasi berikutya.

Ziarah kubur sebagai hal yang pernah dilakukan oleh umat Islam pada zaman dahulu dan memiliki kecendrungan yang masih dilakukan sampai saat ini oleh golongan umat islam yang masih meyakini tentang wasilah atau perantara orang-orang suci. Umumnya umat islam yang mempercayai hal itu dalam waktu tertentu berkunjung kepemakaman tertentu yang dianggap sebagai orang suci semasa hidupnya. Seperti halnya makam Rasullah, Kerabat Beliau, dan Waliyullah.

Mitos memang tidak akan pernah hilang dalam kehidupan umat manusia dimanapun berada, apalagi masyarakat yang masih menjaga nilai-nilai tradisional. Banyak diantara mitos-mitos tersebut yang kadang kala dijadikan sebagai kepercayaan, bahkan melebihi kepercayaan terhadap tuhan sekalipun.Selain itu, mitos 
juga dijadikan sebagai landasan terbentuknya suatu kebudayaan, lalu peradaban.Dan pada akhirnya mitos tersebut dipelihara dan terus dipercaya sampai era modern saat ini.

Hal ini pula yang berlaku bagi masyarakat Suku Sasak Lombok, khususnya lagi masyarakat yang masih kental dengan aroma tradisionalitas.Beberapa mitos diantaranya sangat mengikat pada masyarakat sasak sampai saat ini adalah salah satunya menziarahi makam keramat.Masyarakat suku Sasak akan menjadikan makam keramat sebagai tujuan pertama dalam perjalanan wisatanya. Hal ini diyakini dapat menolak bala sehingga mereka akan terhindar dari musibah selama perjalanan.

Menziarahi kubur orang islam itu disyari'atkan bahkan disunnahkan. Karena Nabi Muhammad SAW, menziarahi kuburan (kuburan kaum muslimin di madinah), dan demikian pula kuburan syuhada. Nabi Muhammad SAW bersabda:

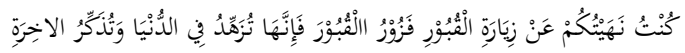

“Duluakupernahmelarang kalian untukberziarahkubur.Namunsekarangketahuilah, hendaknya kalian berziarahkubur.Karenaiadapat melembutkanhati, membuat air mataberlinang, danmengingatkan kalian akanakhiratnamunjangan kalian mengatakanperkataan yang tidaklayak (qaululhujr), ketikaberziarah" (HR. Al Haakim).

Hadist tersebut merupakan salah satu dalil yang di sampaikan oleh rasulullah SAW, dalam memerintahkan umatnya untuk berziarah kubur. Ziarah kubur merupakan salah satu syari'at yang dijalankan oleh umat islam dengan tujuan mempertebal keimanan dan mendekatkan diri kepada allah SWT, serta mengingkatkan manusia kepada kematian yang pasti akan datang kepadanya.

Hubungan masyarakat Sasak dan sejumlah makam keramat (tempat yang diberikan kharomah), sangat erat.Masyarakat Sasak misalnya, memiliki keterikatan emosional dengan makam nenek moyangnya.Karena itu, makam merupakan tempat yang dianggap memberikan nilai spiritualitas yang lebih bagus pada saat mereka melakukan hajatan.Tidak jarang, makam dijadikan tempat bernazar meminta sesuatu dan menimba ilmu.Salah satunya di makam loang baloq. Loang Baloq bukanlah nama seseorang, tapi Loang Balok merupakan bahasa Sasak yang berarti pohon beringin yang berlubang.
Pohon beringin itu sendiri diyakini sudah berumur ratusan tahun, terlihat akar dan batang yang sangat tua.

Makam Loang Baloq adalah kawasan pemakaman yang didalamnya terdapat puluhan jasad.Yang menjadi istimewa dan kerap dikunjungi warga adalah makam Maulana Syech Gaus Abdurrazak, makam Anak Yatim dan Datuk Laut.Syech Gaus Abdurrazak adalah pendakwah Islam dari Baghdad Irak yang menyebarkan Islam di Palembang dan kemudian Lombok sekitar 18 abad lalu. Setelah dari Palembang, ia meneruskan perjalanan dan mendarat di pesisir pantai Ampenan, Mataram. Setelah sampai, ia memberikan petuah-petuah yang bersumber pada ajaran Islam kepada masyarakat setempat.

Makam Syech Gaus Abdurrazak inilah yang berada di lubang tepat di bawah pohon beringin berbentuk persegi panjang dengan lubang ditengah, tempat dimana para peziarah biasanya menaburkan bunga.Untuk masuk kedalam makam yang sudah berkeramik putih ini, peziarah perlu memasuki sebuah pintu masuk.Di samping pintu masuk telah disipakan air untuk pengunjung dan sebuah mushola.Sementara itu, makam Anak Yatim berada di samping bagian luar makam Maulana Syech Gaus Abdurrazak dengan ukuran yang relatif lebih kecil.Di samping makam ini, terdapat makam Datuk Laut dengan bangunan permanen berukuran $3 \times 4$ meter berkeramik warna hitam

Dalam istilah warga masyarakat Lombok (sasak) ini, ziarah kubur dikenal dengan istilah "lalo ziarah aneng makam" dimana seseorang pergi mengunjungi kuburan keluarganya atau seorang tokoh yang dianggap keramat atau wali, kemudian membacakan ayat-ayat al-Qur'an dan pergi bersyukur atas nazarnya.

Masyarakat sasak tidak hanya berziarah, pengunjung yang datang ke kompleks makam ini juga menggelar sejumlah ritual seperti potong rambut anak yang masih balita atau disebut dengan ngurisang.Peziarah biasanya juga menyampaikan nazar dan berdoa di makam agar segera permintaanya segera dikabulkan.Misalnya seperti minta jodoh, panjang umur, sehat dan murah rejeki.Bagi yang menyampaikan nazar tertentu, mereka selalu mengikatkan sesuatu ke akar gantung pohon beringin. Jika nazar mereka dikabulkan, mereka akan kembali lagi ke tempat itu dan membuka ikatan serta 
membayar nazar yang sudah disampaikan.Tradisi dan kebiasaan ini disebut dengan Saur Sesangi.

Kebenaran akan hal-hal tersebut di atas memang misteri yang sulit dipecahkan, kita tidak boleh terlalu percaya dan tidak boleh juga meremehkanhya. Satu yang wajib kita ingat bahwaKepercayaan yang abadi itu hanyalah kepada Allah Swt, Tuhan yang maha Esa.Manusia hanya bisa berencana, Allah yang menentukan.

Fenomena-fenomena diatas adalah perbuatanperbuatan yang bertolak belakang dengan ibadah-ibadah Islam, menentukan waktu-waktu khusus, atau meminta sesuatu di kuburan, padahal dalam Islam hanya disunnahkan pada Hajar Aswad. Dari kasus diatas peneliti tertarik untuk melakukan penelitian mengenai "Tradisi Ziarah Kubur Masyarakat Sasak (Studi Kasus Makam Loang di Lurah Tanjung Karang Kecamatan Sekarbela Kota Mataram)". Karena disana terlihat jelas orang-orang yang berkeyakinan bahwa ketika seseorang melakukan ziarah kubur, maka segala sesuatu yang diinginkan akan terkabul dan lagi para peziarah merasakan ketenangan batin ketika berada dikuburan yang dianggap keramat atau yang dianggap seorang waliyullah terutama makam Loang Baloq (Syech Gaus Abdurrajak).

\section{B. METODE PENELITIAN}

Jenis Penelitian ini adalah penelitian kualitatif dengan pendekatan deskriptif-analitis. Disebut deskriptif karena ia menggambarkan fenomena apa adanya, perkembangan yang tengah terjadi, trend yang mengemuka, dan pendapat yang muncul, baik yang berhubungan dengan masa sebelumnya maupun masa sekarang. Sedangkan pendekatan kualitatif dipakai karena objek penelitian berupa gejala atau proses yang sulit diangakakan, yang lebih mudah dijelaskan dengan deskripsi kata-kata sehingga dinamikanya dapat ditangkap secara lebih utuh. Melalui pendekatan kualitatif dengan metode deskriptif-analitis akan lebih luas dan mendalam mengungkapkan kajian tentang pelaksanaan ziarah kubur ke Makam Loang Baloq. Teknik penentuan infroman yang digunakan dalam penelitian ini adalah menggunakan Sampling Purposiv. Teknik pengumpulan data yaitu observasi, wawancara dan dokumentasi.

\section{HASIL DAN PEMBAHASAN}

\section{Hasul Penelitian}

Berdasarkan hasil penelitian di lapangan mengenai tradisi masyarakat Sasak (Lombok) tentang ziarah kubur dapat diklasifikasikan sebagai berikut.

\section{a) Mengunjungi Makam}

Masyarakat sasak (Lombok), khususnya yang rutin ziarah kubur mengartikan ziarah kubur dengan pekerjaan mengunjungi tempat pemakaman seseorang yang sudah meninggal. persepsi tentang ziarah kubur masyarakat Kelurahan Tanjung Karang, yang pertama mengandung unsur mendatangi, mengunjungi tempat pemakaman atau kuburan tertentu, baik makam orang yang masih terkait dengan hubungan keluarga, sanak famili ataupun orang lain yang dianggap memiliki kelebihan tertentu seperti wali.

\section{b) Berdo'a}

Selanjutnya didapati persepsi masyarakat Desa lain tentang Ziarah Kubur adalah mengandung unsur atau terdapat kegiatan berdo'a. Kegiatan berdo'a disini ada dua pendapat, yang pertama mendo'akan si ahli kubur. kegiatan berdo'a bahwa kegiatan berdo'ayang dimaksud dalam ziarah kubur adalah selain mendo'akan siahli kubur juga berdo'a untuk si peziarah.

\section{c) Mengharap Mendapatkan Berkah atau Barokah}

Masyarakat Sasak memandang kegiatan ziarah kubur adalah kegiatan yang didalamnya terdapat pengharapan untuk mendapatkan berkah atau barokah.

\section{d) Mengingat Akan Kematian}

Sebenarnya banyak pendapat tentang mengartikan ziarah kubur tapi menurut saya pribadi ziarah kubur adalah mengingatkan kita kepada kematian.

\section{e) Wasilah mendekatkan diri kepada Allah}

Esensi dari kegiatan ziarah kubur adalah menurut masyarakat sasak (Lombok) adalah dalam rangka mendekatkan diri kepada Allah. ziarah kubur adalah kegiatan mendatangi kuburan, mendo'akan si ahli kubur, dengan harapan mendapatkan barokah dengan tujuan ibadah yaitu untuk mengingat kematian dan wasilah mendekatkan diri kepada Allah Swt.

\section{f) Untuk Meminta suatu Hajatan}

Sebagian besar masyarakat sasak sangat mempercayai bahwa makam syech gaus abdurrazak dapat 
memberikan pertolongan atau permintaan. Hal ini bisa kita lihat bahwa di pohon beringin sangat banyak bekasbekas ikatan di pohon yang dibuat oleh peziarah. Kapan mulainya ikatan-ikatan itu dibuat orang, sulit ditelusuri kepastiannya.. Karena sudah menjadi kepercayaan sebagian peziarah, salah satu ritualnya adalah setiap peziarah yang mempunyai hajat tertentu membuat ikatan di pohon itu baik dari plastik, benang, rafia, sobekan kain atau maupun lainnya, sambil berjanji bila hajatnya suatu kali telah terkabul mereka akan berziarah ke makam ini lagi dan melepas ikatan tali yang pernah diikatnya tersebut. Jumlah ikatan yang dibuat oleh para peziarah tidak bisa dihitung jumlahnya, sebegitu banyak sehingga mengganggu kebersihan lokasi dan keindahan pohon.

Secara umum, motivasi ziarah ke makam loang baloq tersebut sesungguhnya hampir sama, yaitu seputar untuk mendapat keselamatan, kesehatan, keberkahan, kesembuhan, ungkapan syukur, kemudahan rizki, jodoh, dan nasib baik hasil ( wawancara pada hari 14 Mei 2013). Meskipun demikian, makam sebenarnya memiliki daya tarik sendiri, yang mana hal ini terkait juga dengan kecocokan para peziarah terhadap makam yang diyakini keramat tersebut. Tidak sedikit ditemukan bahwa motivasi para peziarah tidaklah tunggal, hal ini sesuai dengan yang dikatakan oleh bapak Mujahir ketika diwawancarai pada tanggal 14 Mei 2013 dengan waktu yang berbeda beliau menyatakan.."saya sebenarnya tujuan datang kesini bukan karena satu hajatan tetapi banyak hajatan keinginan untuk sembuh dari penyakit, keinginan makin di perbanyak rizki, kesehatan, dan lain sebagainya. Ini membuktikan bahwa para peziarah yang datang ke makam loang baloq memiliki tujuan dan motivasi tersendiri dalam meminta suatu hajatan atau dikabulkanya suatu permintaan.

\section{e) Motivasi Orang Melakukan Ziarah Kubur}

Dalam melakukan sesuatu, tentu manusia selalu bersandarkan pada manfaat yang ia peroleh dari apa yang ia kerjakan. Asas manfaat inilah yang seringkali menjadi motivasi seseorang dalam melakukan aktifitasnya. Begitupun dengan perilaku menziarahi kubur, setiap orang yang pergi untuk menziarahi kuburan sudah pasti memiliki motif-motif yang tentunya memiliki nilai manfaat,
Beragam motivasi para penziarah dalam melakukan ziarah kubur. Antaralain: mencari keberkahan, berharap hajatnya segera dikabulkan oleh Tuhan, mendo'akan ahli kubur, berdo'a untuk mencari kebarokahan bagi diri sendiri, istri dan keluarga, mengingat kematian dengan mendatangi kuburan, mencari ketenangan, dan juga motivasi permasalahan atau problem peziarah, dalam artian peziarah memiliki kesulitan dalam hidup kemudian berziarah ke makam tersebut.

\section{Pembahasan}

Setelah data terkumpul dan diorganisasikan maka pada tahap ini semua data yang diperoleh peneliti simpulkan sebagai berikut:

\section{a) Persepsi Ziarah Kubur}

Tradisi ziarah kubur masyarakat Sasak yang peneliti wawancarai adalah yakni pekerjaan seseorang mengunjungi kuburan dalam rangka mendo'akan orang yang telah meninggal serta mengambil hikmah yang terjadi ketika kita ditanah kubur seperti mengingatkan kita akan nasib kita dikemudian hari, karena kita semua akan mengalami yang namanya kematian.

Sebagaima firman Allah Swt dalam Al-qur'an surah an-Nisaa' ayat 78.

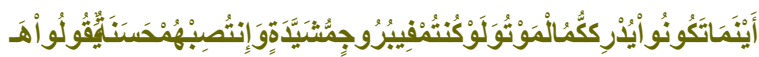

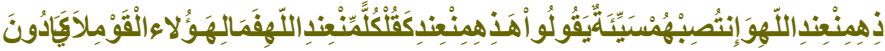
يَفْقَهُونَحَدِيثِ

"Di mana saja kamu berada, kematian akan mendapatkan kamu, kendatipun kamu di dalam benteng yang tinggi lagi kokoh, dan jika mereka memperoleh kebaikan, mereka mengatakan, 'Ini adalah dari sisi Allah,' dan kalau mereka ditimpa suatu bencana mereka mengatakan, 'Ini (datangnya) dari sisi kamu (Muhammad). 'Katakanlah, 'Semuanya (datang) dari sisi Allah. 'Maka mengapa orang-orang itu (orang munafik) hampir-hampir tidak memahami pembicaraan sedikit pun?"

Dari ayat diatas, kita menyadari bahwa kematian adalah suatu yang sakral atau pasti akan terjadi. Oleh karena itu, kematian itu tidak seharusnya di takuti dan kita jauhi. Akan tetapi harus kita persiapkan diri kita.

Atau dengan kata lain bahwa ziarah kubur adalah kegiatan mendatangi kuburan, mendo'akan si ahli kubur, dengan harapan mendapatkan barokah dengan tujuan ibadah yaitu untuk mengingat kematian dan wasilah mendekatkan diri kepada Allah Swt. 
Kemudian apabila hasil tersebut kita diskusikan dengan teori yang peneliti jadikan sebagai suatu landasan teori yang ada di bab II, maka adanya suatu persamaan antara teori dan hasil wawancara, kemudian perbedaan hanya terletak pada pengertian maupun pengungkapannya saja karena mungkin dipengaruhi oleh tingkat pendidikan responden yang peneliti wawancarai.

\section{b) Motif-motif Orang Melakukan Ziarah Kubur}

Yang menjadi motif para penziarah masyarakat Sasak pada dasarnya tidak jauh berbeda seperti yang dinyatakan oleh Bpk. Edi, adalah dalam rangka mengingatkan sesungguhnya kita semua akan mengalami hal yang sama yaitu kematian. Hal ini juga dikemukakan oleh saudara Khusairi saat ditemui pada hari Jum'at, 10 Mei 2013, yang menjadi motif melakukan ziarah kubur adalah untuk mengingatkan kepada kematian serta mendo'akan orang yang sudah meninggal baik dari keluarganya sendiri maupun orang lain dengan membaca Yasin dan Tahlil.

Dari temuan data yang peneliti dapatkan dari hasil wawancara dengan responden yaitu Bpk. Sadili beliau mengatakan bahwa motivasi beliau dalam berziarah kubur adalah mencari barokah dari ahli kubur sehingga segala yang dihajatkannya bisa cepat dikabul.

Hal ini senada kalau kita sesuaikan dengan teori yang ada di landasan teori bahwa sebenarnya adalah dari aspek manfaat seperti mengingatkan kita kepada kematian. Sebagaimana yang diungkapkan oleh Hasyim (1978:115) bahwa pada garis besarnya faidah ziarah kubur ialah ada dua, yakni: untuk mengingatkan segala yang serba ghaib, yaitu akhirat dan segala seluk beluknya, termasuk perkara maut dan untuk mendo'akan kepada yang telah meninggal mendahului kita tentunya dimulai dengan niat yang benar dan hati yang ikhlas semata-mata karena Allah swt. Dilarang dalam menziarahi perkuburan ini ialah meminta sesuatu hajat kepada yang mati itu atau memujanya seperti pemujaan terhadap berhala.

\section{c) Tata Cara Ziarah Kubur}

Kemudian pada permasalahan terakhir peneliti mengambil permasalahan seputar tata cara pelaksanaan ziarah kubur. Pernyataan yang peneliti peroleh dari hasil wawancara dengan salah seorang penziarah adalah: Pada saat berziarah ke kuburan sebaiknya mengikuti tata cara yang baik agar mendatangkan hikmah bagi yang berziarah maupun yang diziarahi karena mengerjakan sesuatu tanpa tahu bagaimana kita bekerja mulai dari memulainya hingga akhirnya, maka tidak akan mendapatkan hasil yang diharapkan. Contoh tata cara ziarah kubur yang dilakukan oleh peziarah misalnya, mengucapkan salam terlebih dahulu ketika hendak memasuki area kuburan dan tentunya kita harus memiliki wudhu terlebih dahulu.

Seperti halnya diungkapkan oleh Godam tentang adab dalam berziarah kubur yang sesuai menurut Islam harus berperilaku sopan dan ramah ketika mendatangi areal pemakaman. Hal ini sesuai dengan sabdanya Nabi Muhammad SAW:

"Dan janganlah mengatakan perkataan yang membuat Allah murka" (HR. Ahmad)

Hadist ini memberikan isyarat bahwa ketika menziarahi kubur hendaknya kita mengatakan perkataan yang layak, tidak membicarakan urusan dunia ketika menziarahi kubur, karena hal yang demikian dapat mendatangkan murkanya Allah.

Masyarakat sasak pada umumnya dan para peziarah pada khususnya menghormati sekali orang orang yang ketika masa hidupnya banyak berjasa seperti halnya mereka menhormati Syech Gaus Abdurrazak, karena mereka menhormati dan meyakini sebagai seorang waliyullah atau tokoh yang menyebarkan agama islam dilombok, begitu pula makam-makam yang dianggap keramat oleh masyarakat atau anggota yang biasa ziarah kubur.

Dari pernyataan-pernyataan di atas, dapatlah disimpulkan bahwa tata cara berziarah kubur menurut masyarakat Sasak (Lombok) adalah pertama, sebelum kita berziarah kubur harus membersihkan badan kita dalam artian kita memiliki wudhu, kedua, kemudian kita mengucapkan salam penghormatan, ketiga, mengirim $\mathrm{Al}$ Fatihah kepada Rasulallah, para Nabi, aulia, leluhur kita dan yang terakhir mengirim do'a yang ditujukan kepada Syech Gaus Abdurrazak, keempat, tawasul, kelima, membaca Al-Fatihah, Al-Ikhlas, Al-Falak, Annas. 


\section{SIMPULAN DAN SARAN}

\section{Kesimpulan}

Sesuai dengan hasil analisis data pada BAB IV, maka dapat ditarik kesimpulan sebagai berikut:

\section{a) Persepsi Ziarah Kubur}

Persepsi masayarakat sasak dalam ziarah kubur merupakan tradisi yang perlu diletarikan secara berkelanjutan, sebagai bentuk perilaku masyarakat dalam hal mendatangi kuburan maka tujuan utamanya adalah untuk mengingat kematian. Nabi Muhammad SAW juga menganjurkankan umatnya untuk menziarahi kubur, karena yang demikain akan mengingatkan kita pada kematian.

\section{b) Motivasi Ziarah Kubur}

Beragam motivasi para peziarah dimakam loang baloQ dalam melakukan ziarah kubur antara lain: mendo'akan ahli kubur, berdo'a untuk mencari keberkahan bagi diri sendiri, istri dan keluarga, mengingat akan kematian dengan mendatangi kuburan dan mencari ketenangan dalam perjalanan hidupnya.

\section{c) Tata Cara Ziarah Kubur}

Tata cara berziarah kubur masyarakat sasak (Lombok)adalah pertama, sebelum kita berziarah kubur harus membersihkan badan kita dalam artian kita memiliki wudhu, kedua, kemudian kita mengucapkan salam penghormatan, ketiga, mengirim Al-Fatihah kepada Rasulallah, para Nabi, aulia, leluhur kita dan yang terakhir mengirim do'a yang ditujukan kepada Agung Mahmud, keempat, tawasul, kelima, membaca Al-Fatihah, Al-Ikhlas, Al-Falak, ANnas,Tahlil dan Yasin, keenam, ditutup dengan do'a.

\section{Saran}

Berdasarkan penelitian ini, maka penulis akan membuat sara-saran yang hendaknya menjadi perhatian bagi peneliti selanjutnya. Diantaranya saran penulis, adalah sebagai berikut:

a) Dalam penelitian ini, penulis menyadari bahwa masih banyak kekurangan terutama dalam menguasai hal-hal yang penting didalamnya. hal tersebut mungkin disebabkan karena kurang maksimalnya pengetahuan penulis atau bisa jadi banyak kelalaian dan keseriusan penulis dalam proses pembelajaran di awal-awal perkuliahan. Oleh karena itu penulis berharap bagi semua mahasiswa ataupun pihak-pihak yang hendak melaksanakan penelitian agar lebih meningkatkan keseriusan dalam proses pembelajaran sebelumnya dengan cara banyak membaca.

b) Dalam judul "Tradisi Ziarah Kubur Masyarakat Sasak (Studi Kasus Makam Loang Baloq)” permasalahan yang penulis angkat hanya terbatas dalam bagaimana persepsi Masyarakat terhadap ziarah kubur, motivasi orang melakukan rutinitas ziarah kubur dan bagaimana tata cara melakukan ziarah kubur. Oleh karena itu, berdasarkan hasil temuan dilapangan, peneliti mengharapkan kepada masyarakat lurah tanjung karang dan masyarakat sasak pada umunya yang masih mempercayai kekeramatan makam, peneliti sarankan agar dalam melakukan ziarah kubur tidak terjadi pertentangan dengan syariat islam. Dengan kata lain, agar masyarakat tersebut tidak secara terus menerus melakukan penyimpangan-penyimpangan aqidah serta hal-hal yang bisa mendekati kesyirikan.

c) Dalam penelitian ini, penulis hanya meneliti Makam Loang Baloq (Syech Gaus Abdurrazak) yang berlokasi di lingkungan Sembalun Lurah Tanjung Karang. Padahal, masih banyak Makam-Makam yang lain dikeramatkan terutama oleh masyarakat sasak pada umumnya dan lebih khusus pada masyarakat tanjung karang seperti; makam batu layar, makam ketaq dan makam loang baloq. Dari hasil penelitian ini, peneliti mengharapkan agar peneliti lainya bisa memakai hasil penelitian sebagai bahan reverensi untuk mendukung obyek penelitian mereka.

\section{DAFTAR RUJUKAN}

Abdullah, Hamid Al-Humaidi. 1999. Bid'ah-bid'ah Kubur. Terjemahan oleh Abdul Rosyad Shiddiq. 2003. Jakarta: Pustaka Al-Kautsar.

Abbas, Siradjuddin. 1969. I'tiqad Ahlussunnah WalJama'ah. Jakarta: Balai Penerbit Pustaka Tarbijah.

Al-Jibrin, Abdul Aziz Bin Abdullah, Cara Mudah Memahami Akidah Sesuai Al-Qur'an, As-Sunnah Dan Pemahaman Salafus Shalih, 2007. Jakarta: Pustaka At-Tazkia.

Asep Ma'mun Muttaqien. 2007. Persepsi Masyarakat Terhadap Ziarah Kubur. Skripsi Fakultas Ushuluddin Instut Dirosat Islamiyah Al-Amien (IDIA) Prenduan Sumenep Madura Jawa Timur.

B. Matthew Milles, Michael Huberman, 1992. Analisis Data Kualitatif. Jakarta: UI Press.

Burhan Bungin, 2008. Penelitian Kualitatif. Jakarta: Kencana Prenada Media Group 
Esterberg. 2002. Metodologi penelitian. Jakarta: Penerbit Bumi Aksara

Dhofir, Syarqawi. 2000. Pengantar Metodologi Riset. Sumenep: Iman Bela.

Farhan, Mamduh, Al-Buhairi. Tth. Kuburan Agung; Menyingkap Fenomena Ketergantungann Kepada Para Wali. Terjemahan oleh A. Hasan Bahori. 2005. Jakarta: Darul Haq

Godam. 2006. Pengertian Ziarah Kubur, dalam http://www.google,/tata cara ziarah kubur.com. diakses tanggal 12 September 2012, Pukul 12 : 00 Wita

Ibnu Shalih bin Hasbullah Abu Muhammad. Tuntanan Praktes Ta'ziyah dan Ziarah Kubur. Pustaka Ibnu Umar Bogor.

Koentjaraningrat. 1990. Pengantar Ilmu Antropologi. Jakarta. PT. Rineka CBPTA.

Koentjaraningrat. 1997. Manusia Dan Kebudayaan Di Indonesia. Jakarta. Perpustakaan Nasional.

Moleong. 2005. Metode Penelitian Kualitatif. Jakarta: Penerbit Rineka Cipta

Poerwanto Hari. 2000. Kebudayaan Dan Linkungan Dalam Perspektif Antropologi. Yogyakarta: Balai Penerbit Pustaka Pelajar Offset

Pudjiwati S, 2007. Apa Yang Dimaksud Dengan Tradisi itu? dalam http://www.google.Definisi Tradisi.

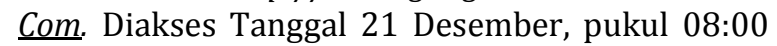
MalamWita

Rahmat, Jalaluddin Dr. 2000.Definisi ziarah kubur, dalam http/www.google./Ziarah Kubur. com. diakses tanggal 05 Desember 2012. Pukul 16:00 Wita

Ridwan, 2006. Sekala Pengukuran Variabel-Variabel Penelitian. Bandung: Alfabeta

Sadirman. 2005. Motivasi dan Interaksi Belajar Mengajar. Jakarta: PT. Raja Grafindo Persada.

Sugiyono. Dr. 2010. Metodolgi Penelitian Pendidikan. Bandung: Penerbit Alfabeta. 